\title{
Economic Integration and Firm-Union Interaction: The Role of Market Structure
}

\author{
K. C. Fung \\ University of California, Santa Cruz \\ Harry Huizinga \\ Tilburg University
}

\begin{abstract}
This paper examines the impact of market integration in the presence of a labor union. Effects on wages, employment, product price, firm profits, and union rents are analyzed. B oth the theoretical model as well as numerical sim ulations show the importance of factors such as the product demand elasticity, the number of firms, the degree of product differentiation, and the nature of competition in the goods market. One surprising result is that union wages and union rents can increase in the presence of market integration. (J E L Classifications: F 10, F12, F 15) \& Key Words: economic integration, labor markets, wages>

* Correspondence Address: K. C. Fung, University of California, Santa Cruz and a Visiting Scholar, Asia/ Pacific Research Center, Stanford University. Research funding from the UC-Santa Cruz Academic Senate faculty grant and the UC-Berkeley Center for German and European Studies is greatly appreciated. We thank Tim B renahan and J ohn Penravel for helpful comments and suggestions. An early version of this paper was presented to a NBER lunch seminar at Stanford University.
\end{abstract}

(O1999 - Institute for International E conomics, Sejong Institution. All rights reserved. 


\section{Introduction}

In recent years, isolated product markets have been increasingly integrated. The deregulation in the airline and trucking industries enlarged the scope of competition to the national level. International trade has intensified competition in many unionized industries. The creation of a U.S.-Canada free trade area in North America and the formation of the European common market in 1992 further integrated international markets and enhanced competition. These developments have revived an earlier interest (see, for example, Segal [1964]) in the linkages between changes in market structure, brought on by deregulation or international trade, and the determination of wages, employment, and profits in the unionized sector.

Freeman and Katz [1987] find that the import share of manufactures is negatively related to changes in union wages and employment. Grossman [1987] shows that imports have not typically been responsible for a decline in employment and wages. However, Abowd [1986] concludes that for most industries, an increase in import competition will lower wages, employment, and revenues. In a later study, Abowd [1987] further finds that higher import shares will adversely affect employment, but has an insignificant impact on wages.

During the 1970s, international competitive pressures in the United States on, for instance, the steel and automobile industries intensified, which led to reduced profitability. At the same time, relative union wages in these sections are reported to have risen. ${ }^{1}$ Lawrence and Lawrence [1985] posit that intensification of competition in these sectors reduced the substitution possibilities between capital and labor, leading to a smaller elasticity of demand for union labor-and a higher union wage. Alternatively, Staiger [1988] shows how increased foreign competition can change the product mix and the labor intensity of production in the union sector, which also explains a fall in the labor demand elasticity and a rise in the union wage premium Grossman [1984] further demonstrates how union wages can fail to change in response to changes to the price of import-competing goods when the union follows a seniority layoff rule. ${ }^{2}$

1. See Lawrence and Lawrence [1985] and references therein.

2. Fung [1992] shows that economic integration can have a pro-competitive or anticompetitive effect, leading to a possibility of higher product prices. 
This paper shows that a set of familiar factors already mentioned by Segal (1964), such as the elasticity of demand, the number of sellers, and the degree of product differentiation, can adequately explain the rise in union wages following market integration. ${ }^{3}$ While detailed models with specialized assumptions can of course rationalize the rise in the union premia, we show that standard concepts of market structure are sufficient to find an explanation.

The impact of market integration on other important variables such as employment, the product price level, union rents, and firm profits is examined as well. Unlike previous articles, the focus here is to demonstrate explicitly how the impact of integration on union sector variables depends on the market structure variables already mentioned: the product demand elasticity, the number of firms, and product differentiation and on whether the producers are quantity-setting or price-setting. ${ }^{4}$ The methodology is to go as far as theory allows and then numerically simulate the effects of the integration of markets for various demand elasticities, different degrees of product differentiation, and different numbers of firms in order to highlight the role of market structure in this issue.

The rest of the paper is organized as follows: in the next section, we will present in turn a theoretical model of firm-union interaction for a monopolist in an isolated market, for Cournot- $\mathrm{N}$ ash firms in a common oligopolistic market, and for B ertrand-N ash firms in a common oligopolistic market. In section III, we will present the numerical simulation results and provide some discussions. In the last section, we will end with some concluding remarks.

\section{Firm-Union Interactions}

\section{A. The Monopolist Case}

This section outlines the the theoretical interaction between a firm and a

3. See Segal [1964], p. 98.

4. A related paper is by Huizinga [1988], who examines the impact of market integration for the case of two firms and unions, homogeneous products, and Cournot competition among the firms. 
labor union in an isolated sector. We consider a market with one firm facing a single labor union, which is the sole supplier of labor to the firm. There is also a competitive sector that yields an alternative, competitive wage of $\hat{w}$. The union is assumed to maximize its labor rents $\mathrm{u}^{\mathrm{m}}$ :

$$
u^{m}=\left(w^{m}-\hat{w}\right) l^{m}
$$

where $\mathrm{w}^{\mathrm{m}}$ is the wage named by the union for the monopoly case and $\mathrm{I}^{\mathrm{m}}$ is the number of workers employed. This assumption is standard in the literature and is equivalent to the objective function of a utilitarian labor union as used in Oswald [1982] and M cD onald and Solow [1981] if the workers are risk neutral. Without loss of generality, we also assume that labor is the only factor of production and that the production of one unit of output requires one unit of labor. The profit function $\Pi^{\mathrm{m}}$ of the monopolist is:

$$
\Pi^{m}=p^{m} x^{m}-w^{m} x^{m}
$$

where $p^{m}$ is the monopoly price of the output $x^{m}$. The firm-union game can be characterized as follows: in the first stage, the union names its optimal wage $\mathrm{w}^{*}$, taking the derived labor demand $\mathrm{I}\left(\mathrm{w}^{*}\right)$ into account. In the second stage, the monopolist takes $\mathrm{w}^{*}$ as given and produces $\mathrm{x}^{*}\left(\mathrm{w}^{*}\right)$. The equilibrium is subgame perfect with the union getting payoffs of $\left(w^{*}-\hat{w}\right) I\left(w^{*}\right)$ and the firm getting payoffs of $p^{*}\left(x^{*}\right)-w^{*} x^{*}$.

For concrete results, we introduce a specific functional form for the product demand: 5

$$
\begin{aligned}
& p^{m}=\left(x^{m}\right)^{-} \quad 0 \leq \quad<1 \\
& x^{m}=l^{m}=\left(w^{m}(1-)\right)^{-1} /
\end{aligned}
$$

with the elasticity of labor demand $\eta^{m}=1 / \alpha$. Rent maximization by the union yield the optimal wage as a function of the competitive wage and the demand elasticity.

5. The restrictions on $\alpha$ ensures a finitely positive union wage and labor demand. 


$$
w^{m}=\hat{w} /(1-\quad)
$$

Together (1)-(5) complete the characterization of the monopoly-union case and all variables can be expressed in terms of $\hat{w}$ and $\alpha$.

\section{B. The Cournot-Nash Case}

Now assume that $\mathrm{n}+1$ monopolist-union sectors, as characterized above, are to compete in a common oligopolistic market. Transportation costs are negligible and there are no barriers to inter-market trade. The regions or countries are fully symmetric in all respects ${ }^{6}$ and the goods produced by the firms are differentiated. The situation can again be described as a one-period, two-stage game where each firm faces $n$ competitors, each with its own union. In the first stage, that $n+1$ unions move first and each names its optimal wage for the Cournot oligopoly case, each taking the impact of the wage-setting on its employment into account. In the second stage, the producers, given the union wage rate, set their outputs and compete in the Cournot-N ash fashion. The payoffs are the respective union rents and firm profits. We again assume that firm i's inverse demand has a specific functional form:

$$
p_{i}^{c}=\left(\left(x_{i}^{c}+n x_{j}^{c}\right) /(1+n)\right)^{-}
$$

where $p_{i}^{c}$ is the price of the Cournot output, $x_{i}^{c}, x_{j}^{c}$, is the Cournot output of any producer other than firm $\mathrm{i}, \mathrm{n}$ is the number of firms, and $\beta$ is the degree of differentiation. Using symmetry, we call drop the subscript i and the union rents $u^{c}$ and the firm profits $\Pi^{c} c a n$ be written as

$$
\begin{aligned}
& u^{c}=\left(w^{c}-\hat{w}\right) l^{c} \\
& \Pi^{c}=\left(p^{c}-w^{c}\right) x^{c}
\end{aligned}
$$

where $w^{c}$ if the union wage, $I^{c}$ is employment and as before we assume one

6. For example, the regions are symmetric in the competitive wage $\hat{w}$, demand elasticity $\alpha$ and product technologies. 
unit of output requires one unit of labor. From the firms' first order conditions for profit maximization and imposing symmetry, we can solve for the labor demand $I^{c}$ as well as the elasticity of the labor demand $\eta^{c}=-(d x / d w)(w / x)$ :

$$
\begin{gathered}
{ }^{c}=\frac{-(1 /)\left[(+1) /(1+)^{2}-2 /(1+n)\right][1-(1+n)]}{\left[(+1) /(1+n)^{2}-2 /(1+n)\right]^{2}-\left((+1) n /(1+n)^{2}-(n) /(1+n)\right)^{2}} \\
l^{c}=x^{c}=\left[w^{c} /(1-/(1+n))\right]^{-1 /}
\end{gathered}
$$

From the unions' rent maximization conditions, we can further obtain

$$
w^{c}=\left[{ }^{c} /\left({ }^{c}-1\right)\right] \hat{w}
$$

The Cournot-N ash case is completely described by (6)-(11).

\section{The Bertrand-Nash Case}

This section characterizes a situation identical to that in (B) above except the firms are Bertrand oligopolists Similar to the earlier description, the $n+1$ unions move first to name their wages, while the firms name their prices in the second stage. Each player collects economic rents as payoffs. To be consistent with the Cournot-Nash case, we will utilize a direct demand for firm i's products obtained by inverting (6):

$$
x_{i}^{B}=\left[\begin{array}{lll}
p_{x_{i}}^{B-1 /}-n p_{x_{j}}^{B-1 /} & ] /(1-n)
\end{array}\right.
$$

Dropping the subscripts by symmetry, using the firms' first order conditions and (12) we obtain the product price and the elasticity of the labor demand in the Bertrand case $\eta^{B}$ :

$$
\begin{aligned}
& p^{B}=w^{B} /[1-(1-n)] \\
{ }^{B}= & -(1 /(1-n))(1 / \quad)\left(2-(1-n)(1+\quad)-n^{2} \quad{ }^{2}\right)(1-\quad(1-n))(1 / \Delta)(14)
\end{aligned}
$$

where $\Delta=(2-(1-n)(1+))^{2}-n^{2} \quad 2$. The rest of the economic variables can again be written: 


$$
\begin{aligned}
& w^{B}=\left({ }^{B} /\left({ }^{B}-1\right)\right) \hat{w} \\
& \Pi^{B}=\left(p^{B}-w^{B}\right) x^{B} \\
& u^{B}=\left(w^{B}-\hat{w}\right) l^{B}
\end{aligned}
$$

We have now characterized the firm-union game and derived explicit expressions for the union wage, employment, output, the product price, and the payoffs to firms and unions under three alternative scenarios: a monopolist and a union in an isolated market, $n+1$ Cournot-Nash oligopolists and $n+1$ unions in a common integrated market, and $n+1$ Bertrand-N ash oligopolists and $n+1$ unions in a common integrated market. We will numerically compare these in the next section and study how changes in the market structure will affect such comparisons.

\section{The Numerical Simulation Results}

The relative values of-the variables associated with a monopolist compared with those of the oligopolists can be found by dividing equations in section 2(A) by those in 2(B) for the Cournot- Nash case and by dividing equations in 2(A) by those in $2(C)$ for the Bertrand- $N$ ash case. These ratios will not depend on the competitive wage since $\hat{w}$ will be canceled. In the numerical simulation, we vary the product demand elasticity $\alpha$ by an interval of 0.01 for different values of $n$ and $\beta$ and examine how the ratios will be changed. B ut since formally the impact of varying $n$ is identical to that of varying $\beta$, we will focus on values of $n \beta$ instead. The values chosen (in order of increasing number of firms and/ or smaller degree of product differentiation) are $n \beta=0.25, n \beta=0.5, n \beta=0.75$, and $n \beta=0.99$. But we will next highlight the more interesting results for each economic variable. We will also show selective graphs on the effects of integration on wages. To save space, we will not show graphs related to other variables. The full numerical simulation results are available upon request from the authors. 


\section{A. Union Wage Rate}

Though Rose [1985] finds that trucking deregulation reduces the wage level, Lawrence and Lawrence [1985] and Staiger [1988] highlight the fact that union wage premium in the U.S. has risen in recent years in the face of increased foreign competition, Fung and Huizinga [1997], and Gaston and Trefler [1995] also show empirically that integration can raise workers' wages. A natural question to consider is to ask whether the union wage rate can increase in our context. To focus on this issue, we construct Table 1 from the simulation results.

Table 1

When Will Union Wage Rate Rise?

\begin{tabular}{|c|c|c|}
\hline & Cournot-Nash & Bertrand-Nash \\
\hline $\mathrm{n} \beta=0.25$ & $\alpha>0.25$ & $\alpha>0.33$ \\
$\mathrm{n} \beta=0.50$ & $\alpha>0.50$ & never \\
$\mathrm{n} \beta=0.75$ & $\alpha>0.75$ & never \\
$\mathrm{n} \beta=0.99$ & never & never \\
\hline
\end{tabular}

From the above, we see that the union wage rate can indeed rise with an intensification of competition. Other things being equal, an increase in the union wage premium is more likely with Cournot competition than Bertrand competition, in the short run (with a higher $\alpha$ ) than in the long run, with a higher degree of product differentiation and/ or a smaller number of firms in the integrated market. Indeed, product differentiation is a necessary condition for wages to rise.

To see why wages can rise, it is useful to decompose the market integration into three steps: (i) counterfactually assuming goods are homogeneous, we can increase the number of firms from 1 to 2 , while maintaining the assumption of a single union; (ii) now we can dispense with the assumption of product homogeneity and assume products are differentiated; and (iii) that the number of unions is increased from 1 to 2 . For the case of Cournot competition, it is easily checked that step (i) does not trigger a change from the monopolist union wage. The introduction of differentiated 
products in step (ii) increases market power, and leads to a higher union wage, while going from 1 to 2 unions in step (iii) of course leads to a lower union wage, as now unions are in indirect competition with each other. Steps (ii) and (iii) have opposite effects on the union wage, and we find that the impact of integration on union wages is indeterminate.

Figures 1-4 highlight graphically the impact on $w$ as $\alpha$ varies (for $n \beta=0.5$ and $n \beta=0.75$ and for both the Cournot-N ash and the B ertrand-N ash cases). The figures correspond to the second and third rows of column one in Table 1. For example, in Figure 1, w starts to rise when a is greater than 0.5 , as is also indicated in Table 1. However, in Figure 2, w monotonically declines with $\alpha$ and it never increases. Similarly, Figure 3 shows that $w$ rises when $\alpha>0.75$, but $w$ always declines in the Bertrand-N ash case, as shown in Figure 4.

\section{B. Union E mployment}

One often-cited potential benefit of market integration is an increase in employment. This is particularly relevant in the European context, where unemployment has stayed persistently high. In Table 2, we focus on the conditions under which union employment will increase.

Table 2

When Will Union Employment Rise?

\begin{tabular}{|c|c|c|}
\hline & Cournot-Nash & Bertrand-Nash \\
\hline $\mathrm{n} \beta=0.25$ & $\alpha<0.70$ & $\alpha<0.78$ \\
$\mathrm{n} \beta=0.50$ & $\alpha<0.82$ & always \\
$\mathrm{n} \beta=0.75$ & $\alpha<0.92$ & always \\
$\mathrm{n} \beta=0.99$ & always & always \\
\hline
\end{tabular}

The increase in employment is more likely in the long run (larger product demand elasticity), with Bertrand firms, a smaller degree of product differentiation and/ or a larger number of firms. Furthermore, the employment expansion effect is also larger with Bertrand firms and a smaller degree of 


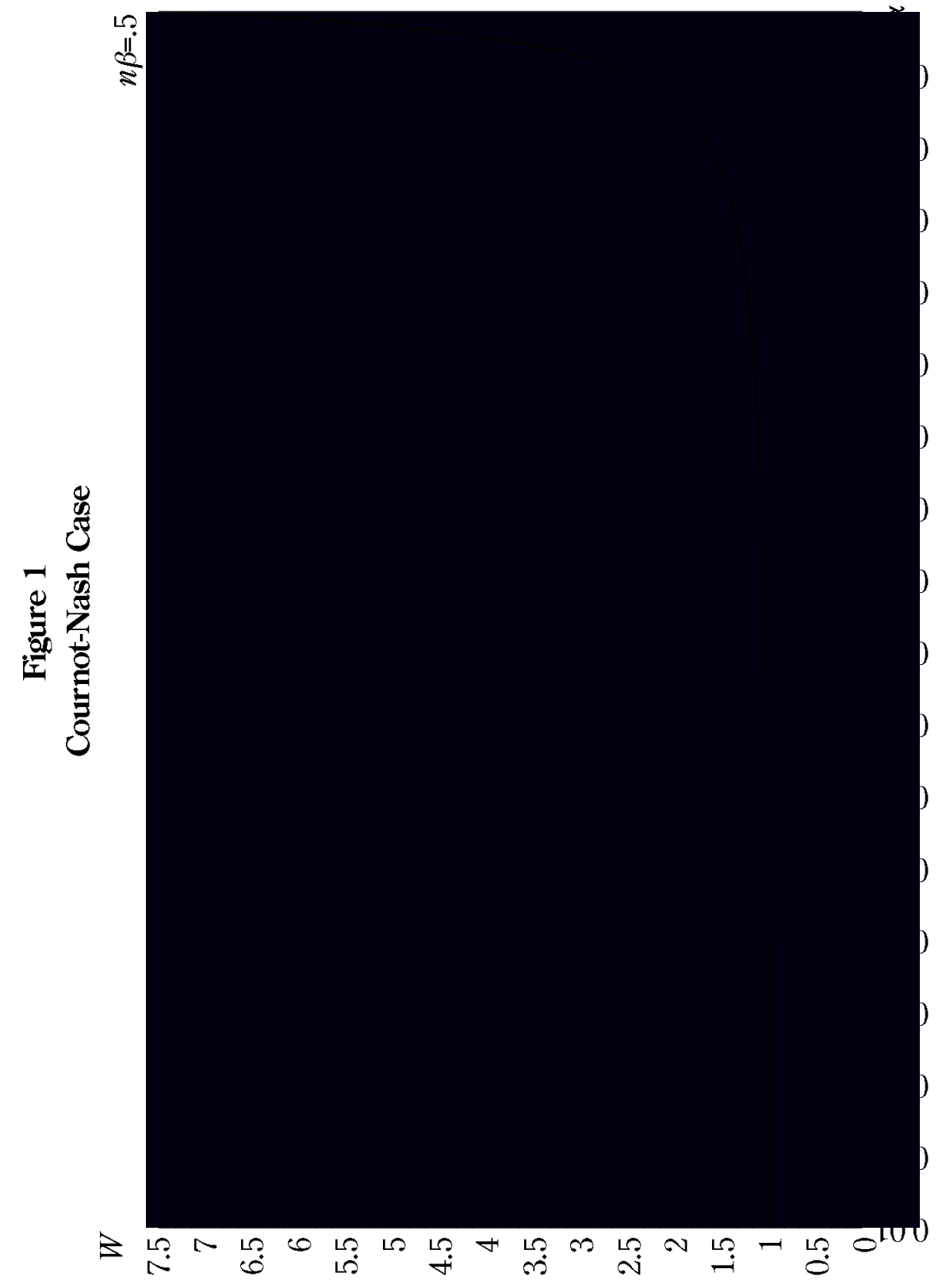




$$
\text { | }
$$




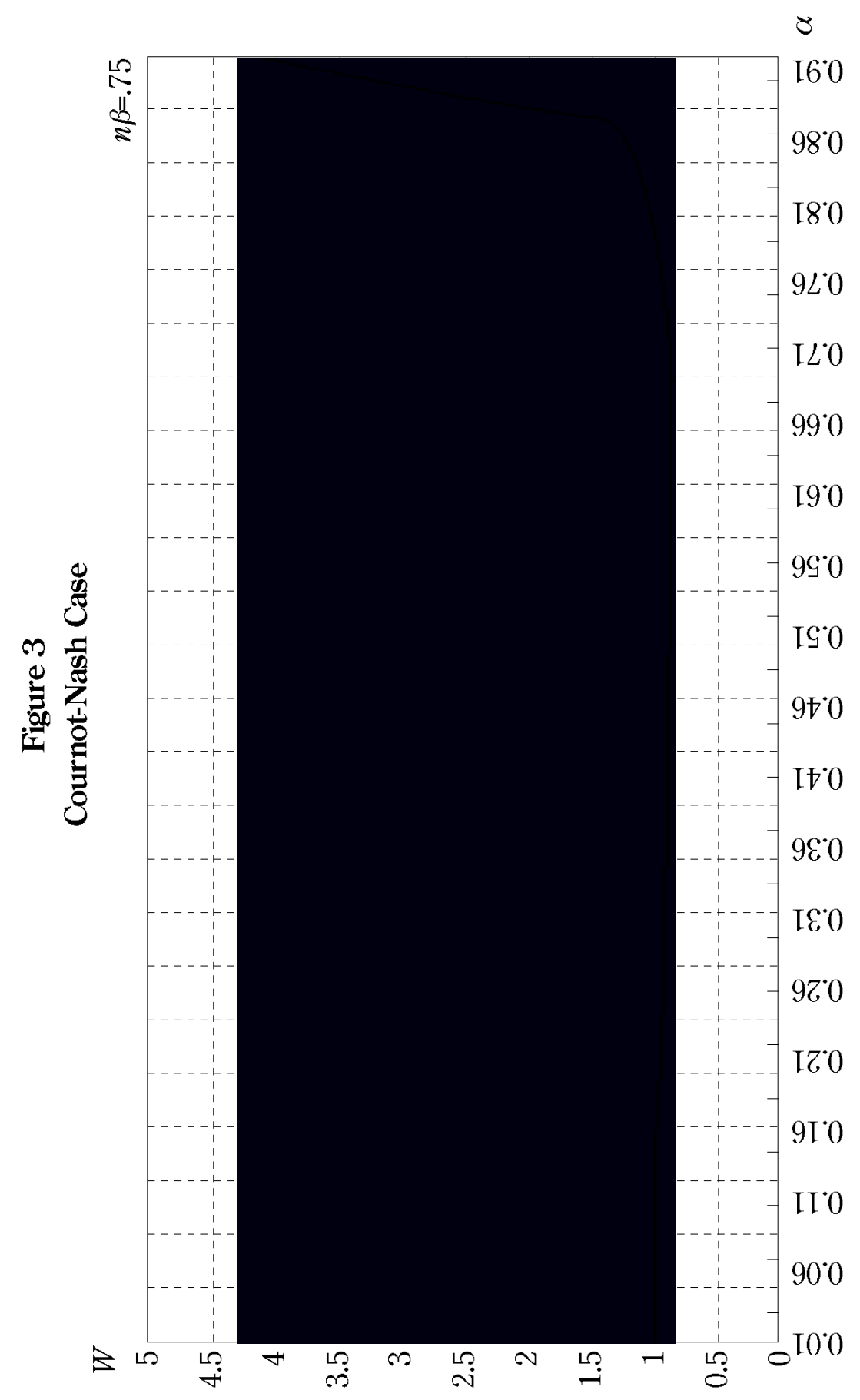




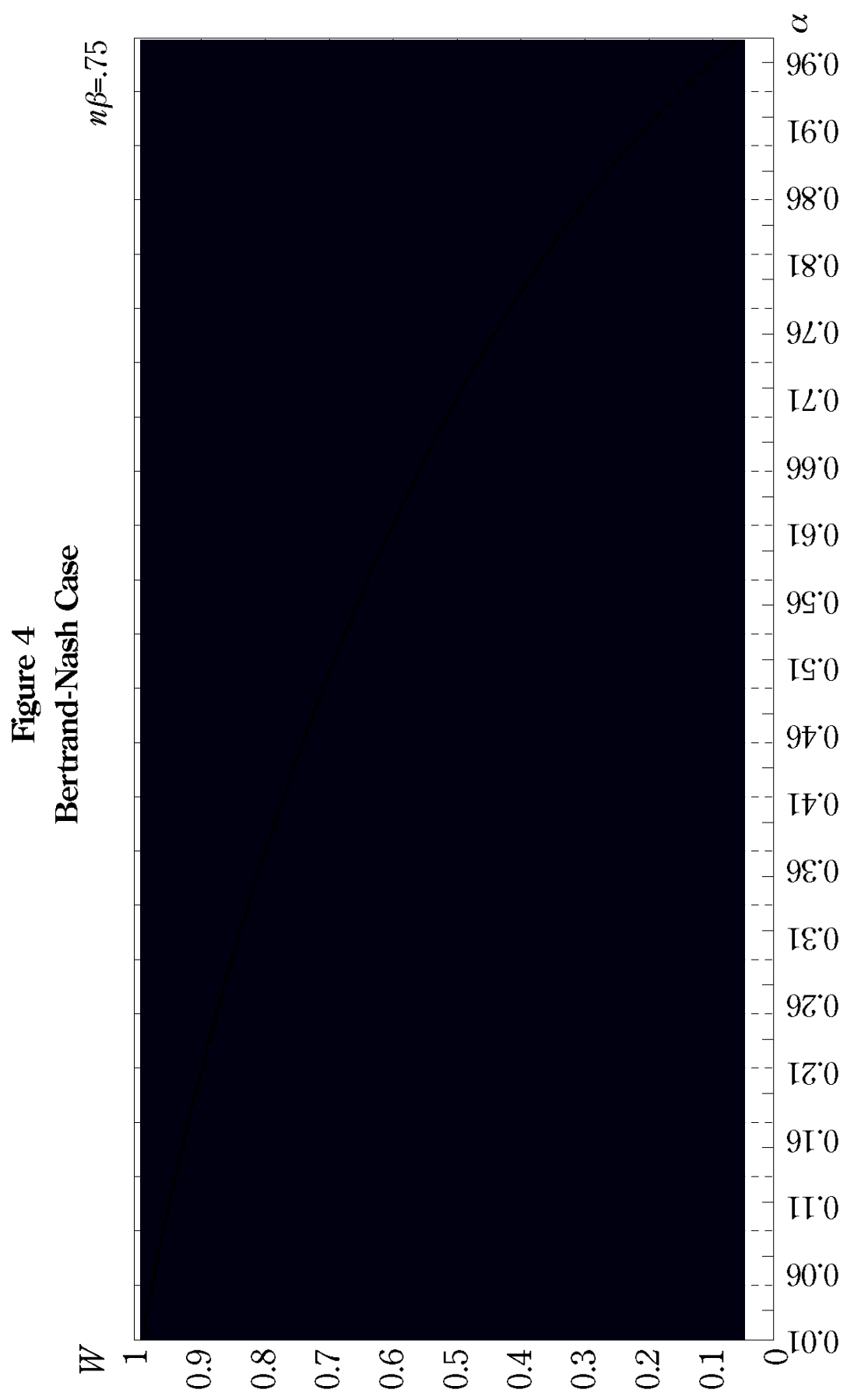


product differentiation and/ or a larger number of firms. ${ }^{7}$

Comparing Tables 1 and 2, we see that union employment can only decline if union wages rise.

\section{Union Rents}

One interesting outcome concerning union rents is that unions will gain under most circumstances, as can be read from below:

Table 3

When Will Union Rents Rise?

\begin{tabular}{|c|c|c|}
\hline & Cournot-Nash & Bertrand-Nash \\
\hline$n \beta=0.25$ & always & always \\
$n \beta=0.50$ & always & always \\
$n \beta=0.75$ & always & always \\
$n \beta=0.99$ & always & $\alpha>0.95$ \\
\hline
\end{tabular}

Concentrating on the cases when unions do gain, we find that the rents will go up more if the product market consists of Bertrand firms and generally if the products are more homogeneous and/ or the number of firms is larger. ${ }^{8}$ In the extreme case of Bertrand competition and homogeneous products, it is easy to see that market integration reduces the union wage to competitive wage level. This is true because if at any other wage level the two union wages were equal, then each union would face a labor demand elasticity of infinity and reduce its wage.

7. As for the effect of $\alpha$ on employment expansion, a larger $\alpha$ can lead to a larger or smaller employment ratio, depending on the range of $\alpha$.

8. The only exception is for $\alpha \geq 0.95$, then unions gain less when $n \beta$ goes from 05 to 0.75 . As for the demand elasticity, the rent ratio typically first rises, then falls as $\alpha$ increases. 


\section{Product Price}

Under most circumstances, the product price will decline with market integration, as can be seen in Table 4.

Table 4

When Will Product Price Decline?

\begin{tabular}{|c|c|c|}
\hline & Cournot-Nash & Bertrand-Nash \\
\hline $\mathrm{n} \beta=0.25$ & $\alpha<0.70$ & $\alpha<0.78$ \\
$\mathrm{n} \beta=0.50$ & $\alpha<0.82$ & always \\
$\mathrm{n} \beta=0.75$ & $\alpha<0.92$ & always \\
$\mathrm{n} \beta=0.99$ & always & always \\
\hline
\end{tabular}

The product price is more likely to decline with Bertrand firms, in the long run (larger product demand elasticity), more homogeneous products, and/ or a larger number of producers. The extent of the price decline will also be larger with Bertrand firms and with more product homogeneity. ${ }^{9}$ of course, product price declines in Table 4 mirror employment and output increases in Table 2.

\section{E . Firm Profits}

Producers will likely lose from an intensification of competition, though it is interesting that in some cases firm profits can still increase (Table 5). The impact of integration on firm profits is ambiguous, because firms may be confronted with a decline in the output price as well as lower wage demands from their unions.

9. In addition, the price ratio will typically first decline, then rise as the $\alpha$ rises 
Table 5

When Will Profits Increase?

\begin{tabular}{|c|c|c|}
\hline & Cournot-Nash & Bertrand-Nash \\
\hline $\mathrm{n} \beta=0.25$ & $\alpha<0.10$ & $\alpha<0.08$ \\
$\mathrm{n} \beta=0.50$ & $\alpha<0.19$ & $\alpha<0.02$ \\
$\mathrm{n} \beta=0.75$ & $\alpha<0.25$ & never \\
$\mathrm{n} \beta=0.99$ & $\alpha<0.30$ & never \\
\hline
\end{tabular}

Other things being equal, profits will more likely increase with a larger demand elasticity. Cournot firms are more likely to gain than Bertrand firms. For Cournot producers, profits will more likely increase with less product differentiation, while for Bertrand firms, profits will more likely increase with more product differentiation.

Will profits be higher for Cournot firms or Bertrand firms? From Table 6 below, we see that with a high $\mathrm{n} \beta$, Cournot firms are better off, but with a low $n \beta$, Bertrand firms can be better off if the product demand elasticity is sufficiently low.

\section{Table 6}

\section{Comparing Profits under Cournot and Bertrand}

\begin{tabular}{|c|c|c|}
\hline & Cournot-N ash & Bertrand-Nash \\
\hline$n \beta=0.25$ & $\Pi^{C}>\Pi^{B}$ & $\alpha \in(0.01,0.43)$ \\
& $\Pi^{B}>\Pi^{C}$ & otherwise \\
$n \beta=0.50$ & $\Pi^{C}>\Pi^{B}$ & $\alpha \in(0.01,0.79)$ \\
& $\Pi^{B}>\Pi^{C}$ & otherwise \\
$n \beta=0.75$ & $\Pi^{C}>\Pi^{B}$ & $\forall \alpha$ \\
$n \beta=0.99$ & $\Pi^{C}>\Pi^{B}$ & $\forall \alpha$ \\
\hline
\end{tabular}

\section{Conclusion}

In this paper, we examine the impact of allowing previously isolated monopolist-union to compete in a common oligopolistic market on important economic variables such as the union wage, employment, product price, union rents, and firm profits. The impact is first analyzed theoretical- 
ly, then it is shown through a numerical simulation exercise that the effects on these variables depend critically on market structure characteristics such as the degree of product differentiation, the number of firms, the product demand elasticity, and whether the producers are quantity-setting or price-setting. One highlighted result is that the union wage premium can increase with increased competition, a puzzling phenomenon that actually occurs in the U.S. manufacturing sector and is found econometrically in Fung and Huizinga [1997] and Gaston and T refler [1995]. A second result is that market integration can reduce employment, particularly if the product demand elasticity is large, the goods are more differentiated, the number of firms is small, and if the producers are Cournot players. The result is of particular interest to those who study the impact of the formation of a common market in Europe, where unemployment has remained stubbornly high. We further study the distributional effects of market integration. Consumers generally gain as the product price tends to fall and the number of varieties rises. Unions will typically gain. Firm profits can also increase with intensification of competition since although product price tends to decline, producers may also be able to obtain wage concessions from the unions. Thus market integration can be Pareto improving for consumers, unions as well as producers.

\section{References}

Abowd, J. [1996], "The Effects of International Competition on Collective Bargaining Settlements in the United States," mimeo, Princeton University, N ovember.

Abowd, J . [1987], "The E ffects of International Trade on Collective Bargaining Agreements: Evidence from Canada," mimeo, Cornell University, September.

Freeman, R. and L. Katz [1987], "Industrial Wage and Employment Determination in an Open Economy," mimeo, Harvard University, September.

Fung, K. C. [1992], "Economic Integration As Competitive Discipline," International E conomic Review 33(4); 837-847.

Fung, K. C. and H. Huizinga [1997], "Can F reer Intra-Industry Trade Raise Wages: Evidence From Canada," mimeo, University of California, 


\section{Santa Cruz.}

Gaston, N. and D. Trefler [1995], "Union Wage Sensitivity to Trade and Protection: Theory and Evidence," Journal of International Economics 39; 125.

Grossman, G. [1984], "International Competition and the Unionized Sector," Canadian Journal of E conomics 17, August; 541-56

Grossman, G. [1987], "The E mployment and Wage E ffects of Import Competition in the United States," Journal of International E conomic Inte gration $1 ; 1-23$.

Huizinga, H. [1988], "Union Wage Bargaining and Industry Structure," mimeo, Stanford University.

Lawrence, C. and R. Lawrence [1985], "The Dispersion in U.S. M anufacturing Wages: An Endgame Interpretation," B rookings Papers on Econom ic Activity 1; 47-106.

M cDonald, I. and R. Solow [1981], "Wage Bargaining and Employment," American E conomic Review 71; 896-908

Oswald, A. [1982], "The M icroeconomic Theory of the Trade Union," Eco nomic Journal 92; 576- 595.

Rose, N. [1985], "The Incidence of Regulatory Rents in the M otor Carrier Industry," Rand Journal of E conomics, Autumn.

Segal, M. [1964], "The Relation between Union Wage Impact and Market Structure," Quarterly Journal of E conomics 78; 96-114.

Staiger, R. [1988], "Organized Labor and the Scope of International Specialization," Journal of Political E conomy 96; 1022-1047. 